\title{
Spatial and temporal boundaries to gene flow between Chaenocephalus aceratus populations at South Orkney and South Shetlands
}

\author{
Chiara Papetti ${ }^{1}$, Emanuele Susana ${ }^{1,2}$, Tomaso Patarnello ${ }^{1,3}$, Lorenzo Zane ${ }^{1, *}$ \\ ${ }^{1}$ Department of Biology, University of Padova, Via G. Colombo 3, 35121 Padova, Italy \\ ${ }^{2}$ Centro Analisi Chimiche Srl, Via Avogadro 23, Rubano 35030 (PD), Italy \\ ${ }^{3}$ Department of Public Health, Comparative Pathology and Veterinary Hygiene, University of Padova, \\ Viale dell'Università 16, Agripolis 35020 Legnaro (PD), Italy
}

\begin{abstract}
The black-fin icefish Chaenocephalus aceratus is among the most abundant fish species on the Antarctic continental shelves of the Scotia Arc, and Bouvet Island. We genotyped 11 microsatellite loci in $C$. aceratus population samples from South Orkney, southern South Shetlands, and Elephant Island (northern South Shetlands) collected in 2002 and 2006. This investigation further develops a previous study on the species reporting the presence of one panmittic population in southern South Shetlands and Elephant Island, with genetic differentiation between year classes. Our results reveal a more complex pattern of differentiation than shown previously, as genetic differences occur both at the temporal level at Elephant Island and at the geographic scale between southern South Shetland-Elephant Islands and South Orkney population samples. In particular, the magnitude of genetic differentiation at the temporal scale, the relatively high effective population size $\left(N_{\mathrm{e}}\right)$ and high gene flow indicate that genetic differentiation is not only driven by geographic distance. At present, our results should be taken into account when defining conservation measures and management boundaries in regions where fishery is still open or where other Antarctic fish species are still exploited.
\end{abstract}

KEY WORDS: Chaenocephalus aceratus $\cdot$ Icefish $\cdot$ Southern Ocean $\cdot$ Microsatellite $\cdot$ Automatic allele calling $\cdot$ Geographic and temporal differentiation $\cdot$ Gene flow $\cdot N_{\mathrm{e}}$

\section{INTRODUCTION}

The black-fin icefish Chaenocephalus aceratus (Perciformes, Notothenioidei, Channichthyidae) is distributed in the Scotia Sea (western Atlantic Sector of the Southern Ocean) along the Scotia Arc. The species is also present further east at Bouvet Island (eastern Atlantic Sector of the Southern Ocean) (Kock \& Jones 2002). Larvae of C. aceratus were also found near Arthur Harbor (Anvers Island, Antarctic Peninsula [AP]; Hemmingsen \& Douglas 1970) and, although this finding has never been further confirmed, this would extend the distribution further west and south. The Scotia Sea extends from $20^{\circ}$ to $65^{\circ} \mathrm{W}$ and is bounded by the Weddell Sea to the south, the South Atlantic Ocean to the north and east, and the Pacific Ocean to the west of Drake Passage (our Fig. 1; Brandon et al. 2004). The regional circulation is dominated by the eastward flow of the Antarctic Circumpolar Current (ACC) (Orsi et al. 1995) that enters the Scotia Sea through Drake Passage (Cunningham et al. 2003). There is also a strong northward outflow of waters from the Weddell Sea occurring at a depth interval between 2000 and $4000 \mathrm{~m}$ (Naveira Garabato et al. 2002, Schodlok et al. 2002). As exemplified by drifters and modeling of krill transport (Fach \& Klinck 2006), the ACC current creates a preferential passive dispersal route from southwest sites to the northeast 


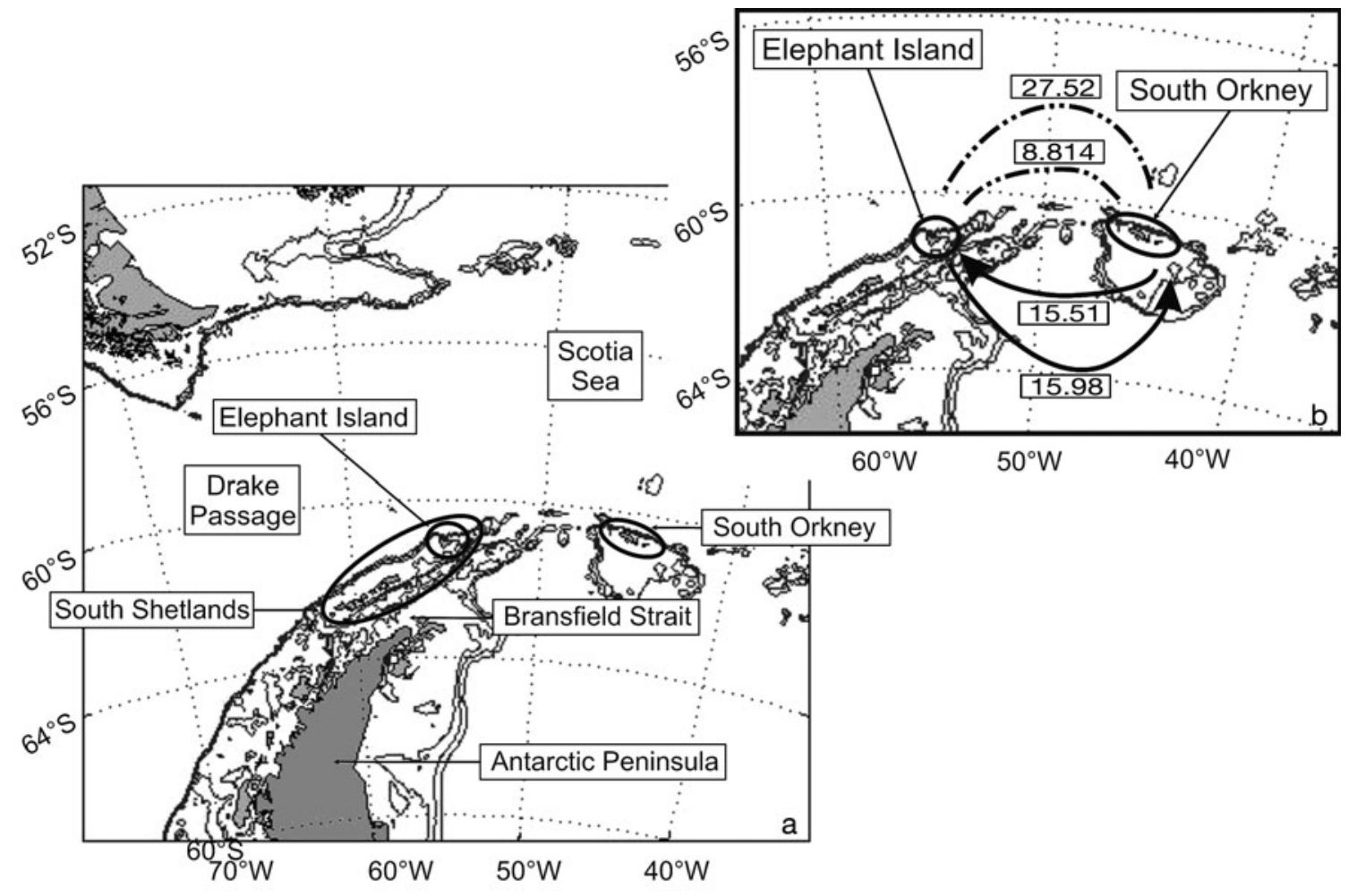

Fig. 1. (a) Sampling locations of Chaenocephalus aceratus. Isobaths in $500 \mathrm{~m}$ intervals encompass the depth range between 500 and $1500 \mathrm{~m}$. (b) Gene flow between population samples/geographic regions of Elephant Island and South Orkneys (collection year 2006). Gene flow values (effective number of migrants per generation, $N_{\mathrm{e}} \mathrm{m}$ ) are reported in boxes. $N_{\mathrm{e}} \mathrm{m}$ values calculated by Wright's and Slatkin's methods are indicated over dashed lines; values from Migrate are reported under solid lines; arrows indicate migration direction only for MIGRATE results

ones, potentially creating a source-sink relationship between populations of organisms inhabiting the area.

The continental shelves of the AP and Scotia Arc Islands host a rich biological community (Moffat et al. 2008) where Chaenocephalus aceratus is among the most abundant fish species (Kock \& Stransky 2000). Adults occur at depths of 200 to $400 \mathrm{~m}$, although some individuals have been found beyond $700 \mathrm{~m}$ depth (Kock \& Jones 2002, Kock 2005). From a commercial point of view, the black-fin icefish represented an important fishery resource until the 1989-1990 season (Kock 1992). After a deep exploitation of notothenioid stocks, commercial finfish harvest was banned in 1990-1991 by the Commission of the Convention for the Conservation of Antarctic Marine Living Resources (CCAMLR) along the Southern Scotia Arc and restricted to South Georgia and South Sandwich Islands (CCAMLR Conservation Measures 32-03 and 32-04).

Kock \& Jones (2002) observed a remarkable fluctuation in frequencies of age classes of Chaenocephalus aceratus over shelf areas of South Shetlands, including Elephant Island, and across most sectors of the South Orkneys shelf (Kock \& Stransky 2000, Kock \& Jones
2005). In fact, while in some years, Age Class I (1 yr old individuals) was very frequent in bottom-trawl hauls, in other years the youngest catches included only individuals from Age Class II. Kock \& Jones (2002) suggested that changes in feeding conditions between years causes differences in the mid-water distribution of these fish (and consequently its abundance in bottom trawls) from year to year. C. aceratus shows a developmental change in feeding habit, from larvae that feed on furcilia (larval krill stages), to juveniles that mainly feed on mysids and krill. After having become 3 to $4 \mathrm{yr}$ old, mature adults change their diet and display a benthic sit-and-wait feeding strategy, mostly targeting fish (Kock et al. 2000). Only occasionally do adults ascend to near-bottom or mid-water layers to feed on krill (Siegel 1980, Takahashi \& Iwami 1997).

While most studies on Chaenocephalus aceratus concern mainly growth, ecology, life history, or behavioral aspects (see e.g. Flores et al. 2004, La Mesa et al. 2004, Detrich et al. 2005), recently a few investigations have focused on the population genetics of the species (Papetti et al. 2007, Susana et al. 2007). In waters of the Southern Ocean, understanding the role of factors that may influence population genetic structure has gained 
additional attention due to the increasing need of proper management of natural resources (FAO 2001). Failure to detect hidden stock units can lead to local over-fishing and in extreme cases to severe declines in species abundance (Frank \& Brickman 2001). This also means that temporal monitoring of stock genetic structure should be implemented as a further strategy in management plans in areas still exploited, despite the difficult accessibility of Southern Ocean to obtain replicates from different years.

Our study follows a previous investigation on Chaenocephalus aceratus, where one panmittic population was found at Elephant Island and southern South Shetlands (Papetti et al. 2007). This result is in agreement with parasitic infestation patterns and data on spawning time/maturity stages that documented the presence of a single population on the microgeographic scale of South Shetlands (Kock \& Möller 1977, Siegel 1980). Studies on parasite infestation, however, suggested the existence of at least 3 differentiated stocks off the shelves of South Georgia, South Orkney, and South Shetland Islands (Siegel 1980, Sosinski \& Janusz 2000), prompting the analysis of new population samples. Genetic markers also evidenced temporal variability in the genetic pool of $C$. aceratus (Papetti et al. 2007) as there was found to be significant differentiation between year classes. While studies on marine organisms usually assume genetic homogeneity of broadly distributed species (Ward et al. 1994), this view is challenged by the growing body of literature that revealed genetic differentiation at geographic scales (Patarnello et al. 2007), and recently by several studies documenting genetic differentiation at the temporal scale, for instance in Gadus morhua, Merluccius merluccius, Pleuronectes platessa, and Clupea harengus (Ruzzante et al. 1999, Lundy et al. 2000, Hoarau et al. 2002, Nielsen et al. 2003, Bekkevold et al. 2005, Hede Jørgensen et al. 2005, O'Leary et al. 2006). For example, Lundy et al. (2000) reported temporal differentiation among hake ( $M$. merluccius) population samples collected from the Bay of Biscay despite temporally stable spawning sites and juvenile retention. In particular, this suggests that temporal changes at microsatellite allele frequency were far more important than geographic distances between populations (Lundy et al. 2000), similarly to what is observed in the European eel (Dannewitz et al. 2005, Maes et al. 2006).

Large variance in reproductive success and temporal spawning patterns, low effective population size $\left(N_{\mathrm{e}}\right)$, fluctuations in recruitment, selection on early life stages, and gene flow from genetically differentiated populations are common in marine fish and may all act in preventing genetic homogeneity between year classes or temporal replicates, and in maintaining unstable population units (McQuinn 1997). The 'fluctuating genetic patchiness' defines the mix of these factors that contribute to genetic differentiation among temporal replicates from the same location (Hauser et al. 2002, Hellberg et al. 2002, Hedgecock et al. 2004, Hede Jørgensen et al. 2005).

In this context, the present study is aimed at verifying whether: (1) the genetic structure of Chaenocephalus aceratus is stable over time in previously analyzed sampling areas, (2) there are differentiated population units on a larger geographic scale, and (3) levels of differentiation are divergent at a geographic/ temporal scale. In order to address these points, we genotyped 11 microsatellite loci in 4 C. aceratus population samples from 3 locations (South Orkney, southern South Shetland, and Elephant Islands) collected during different years (2002 and 2006). This is, to our knowledge, the first attempt to dissect temporal and geographic variation in a notothenioid species using microsatellites. While our study concerns samples collected in areas closed to finfish harvest (CCAMLR Conservation Measures 32-03 and 32-04), we expect that our results can be useful for future management plans in still-exploited areas of the Scotia Sea such as South Georgia and South Sandwich Islands.

\section{MATERIALS AND METHODS}

Sampling. Population samples analyzed in the present study were collected at 3 different sites of the Scotia Sea, namely Elephant Island, southern South Shetlands, and South Orkneys (Table 1, Fig. 1a); at Elephant Island, samples were obtained from similar locations in 2002 and 2006. In the present study, population samples and temporal replicates from South Shetland Islands (King George, Livingston, and Elephant Islands) are conventionally defined as 'southern South Shetlands and Elephant Island' populations, due to their coordinates origin (our Table 1; see also Papetti et al. 2007 and their online supplementary materials). A small piece of muscle tissue was collected from each specimen and preserved in absolute ethanol until the molecular analysis. For the 2006 population samples, age information was not available; for this reason analysis considering age classes differentiation was not performed.

Genetic and statistical analyses. DNA extraction and genotyping: Total genomic DNA was extracted from 10 to $100 \mathrm{mg}$ of absolute ethanol-preserved muscle tissue from 95 specimens collected at South Orkney and Elephant Islands (Table 1) according to Patwary et al. (1994). Eleven microsatellite loci were amplified as described in Papetti et al. (2007). Seven of these were species-specific (Susana et al. 2007) while 4 loci, 
Table 1. Chaenocephalus aceratus. Population samples used in this study. N: sample size

\begin{tabular}{|c|c|c|c|c|c|}
\hline $\begin{array}{l}\text { Population sample } \\
\text { geographic origin }\end{array}$ & Acronym & $\begin{array}{l}\text { Sampling } \\
\text { year }\end{array}$ & $\begin{array}{l}\text { Sampling area } \\
\text { coordinates }\end{array}$ & $\begin{array}{l}\text { Sampling } \\
\text { cruise }\end{array}$ & $\mathrm{N}$ \\
\hline \multirow{2}{*}{ Elephant Island } & EI02 & 2002 & $--^{\mathrm{a}}$ & ANT-XIX/3 AWI ${ }^{b}$ & 202 \\
\hline & EI06 & 2006 & $61^{\circ} 04^{\prime} 35^{\prime \prime} \mathrm{S}, 56.01^{\circ} 10^{\prime} \mathrm{W}$ & JR145 BAS ${ }^{\mathrm{C}}$ & 47 \\
\hline \multicolumn{6}{|l|}{ Shetlands } \\
\hline South Orkney & SO06 & 2006 & $60^{\circ} 54^{\prime} 22^{\prime \prime} \mathrm{S}, 46^{\circ} 30^{\prime} 59^{\prime \prime} \mathrm{W}$ & $\begin{array}{r}\text { JR145 BAS }{ }^{\mathrm{c}} \\
\text { Total }\end{array}$ & $\begin{array}{r}48 \\
342\end{array}$ \\
\hline \multicolumn{6}{|c|}{$\begin{array}{l}\text { a'See Table 1S in Papetti et al. (2007) online supplementary materials } \\
\text { bCCAMLR fish survey and ANDEEP I cruise PFS 'Polarstern' ANT-XIX/3, AWI: Alfred Wegener Institute, Bremerhaven, } \\
\text { Germany; population sample previously analyzed in Papetti et al. (2007) } \\
\text { 'JR145 cruise with RRS 'James Clark Ross', BAS, British Antarctic Suvey, samples collected under NERC AFI 6/16 grant to } \\
\text { G. Carvalho and kindly provided by J. Rock and T. North }\end{array}$} \\
\hline
\end{tabular}

isolated from Chionodraco rastrospinosus (Notothenioidei, Channichthyidae) (Papetti et al. 2006), crossamplified in Chaenocephalus aceratus. Fragment analysis was performed at the BMR Genomics Molecular Biology service (www.bmr-genomics.it). In order to perform a comparable allele sizing between our previous study and the present study, 10 individuals collected during 2002 and already genotyped in Papetti et al. (2007) were randomly chosen and re-genotyped so as to test the consistency of allele amplification and sizing. Moreover, in order to minimize the negative consequences of a poor allele calling, binning was automated with the software FLEXIBIN ver. 2 (Amos et al. 2007) and all samples from Papetti et al. (2007) were rescored. Allele calling is known to be prone to a high error rate when new alleles are found, where reference standards are not available or, as in the present case, when scoring new samples (Amos et al. 2007). The scoring was then manually checked by the authors and loci were analyzed for null alleles presence with MicRocheCKeR ver. 2.2.3 (van Oosterhout et al. 2004). Our procedure allowed checking for discrepancies between present and previous scoring and results from the previously manually scored alleles were confirmed using automated scoring.

Genetic diversity, Hardy-Weinberg equilibrium, linkage disequilibrium: Descriptive statistics such as allele size range $\left(S_{\mathrm{R}}\right)$ in base pair (bp), number of alleles $\left(N_{\mathrm{a}}\right)$, and most common allele frequency at each locus were computed with POWERMARKER ver. 3.25 (Liu \& Muse 2005). Observed heterozygosity $\left(H_{\mathrm{O}}\right)$ and unbiased gene diversity $\left(H_{\mathrm{E}}\right)$ were calculated using the Windows Excel add-in package GENAlEx ver. 6 (Peakall \& Smouse 2006). Genotypic linkage disequilibrium tests between pairs of loci in each population and global tests for conformity with Hardy-Weinberg equilibrium were performed across loci and across populations using GENEPOP, online version (Raymond \& Rousset 1995).
Population structure: Differentiation tests between population samples were performed using CHIFISH ver. 1.3 (Ryman 2006). The software tests the hypothesis of no allele frequency difference among populations at each locus by means of Pearson's traditional chi-squared and Fisher's exact test. FSTAT ver. 2.9.3.2 (Goudet 1995) was used to compute the allelic richness $\left(A_{\mathrm{R}}\right)$ and the overall and population pairwise $F_{\mathrm{ST}}$. The $A_{\mathrm{R}}$ was based on the smallest sample size between populations, of 45 diploid individuals (population from South Shetlands). The estimation of the probability of $F_{\text {ST }}$ was determined using 1000 permutations and bootstrap replicates for all comparisons. A standardized measure of population divergence $\left(F^{\prime}{ }_{\mathrm{ST}}\right)$, independent from the levels of heterozygosity, was calculated to allow comparisons between populations (Hedrick 2005). The program ReCODEDATA ver. 1.0 (available from www.bentleydrummer.nl/software/ index.html) was used to recode the data set so that each population sample had unique alleles, allowing the estimation of the maximum level of population differentiation. To estimate the standardized level of population subdivision $\left(F^{\prime}{ }_{\mathrm{ST}}\right)$, each actual estimate of population differentiation $\left(F_{\mathrm{ST}}\right)$ was divided by the maximum $F_{\mathrm{ST}}$ value obtained from the recoded dataset. The $95 \%$ confidence intervals were estimated by 1000 bootstrap replicates over loci and probability values were determined by 1000 permutations. For all our tests with multiple comparisons, statistical significance level was adjusted, against type I errors, using standard Bonferroni correction (Rice 1989). The nominal significance level was set at 0.05 .

Population structure at the geographic level was investigated by a landscape genetic approach using the program BARRIER ver. 2.2 (Manni et al. 2004) to find the largest breaks in genetic structure of our populations collected at different locations (South Orkney, South Shetland, and Elephant Islands). Using a Delaunay triangulation obtained with the Voronoï tessella- 
tion estimator (Manni et al. 2004), BARRIER projects a geometrical representation of the populations. As output, the software provides the putative genetic barriers starting with the pair of populations with the largest genetic distance using the Monmonier maximum differential algorithm (Monmonier 1973). Robustness of the barriers is determined by re-sampling the distance matrices 100 times. Two datasets were analyzed, excluding each time 1 of the 2 temporal replicates (Elephant Island 2002 and 2006). As a parallel approach to graphical representation of genetic barriers, we tested for the presence of correlation between geographic and genetic distance performing a Mantel's test using the procedure of Smouse (1986) implemented within the Windows Excel add-in package GENAlEx ver. 6 (Peakall \& Smouse 2006). Statistical significance of the values was obtained via 9999 random permutations.

Gene flow and effective population size: The effective number of migrants per generation $\left(N_{\mathrm{e}} \mathrm{m}\right.$, population effective size per migration rate) was estimated for the Elephant Island 2006-South Orkneys 2006 (EI06/ SO06; for complete list of acronyms see Table 1) pair of populations because they represent 2 different locations sampled at the same time (2006). $N_{\mathrm{e}} \mathrm{m}$ for this populations pair was obtained using 2 methods: (1) Wright's formula: $F_{\mathrm{ST}}=1 /\left(1+4 N_{\mathrm{e}} \mathrm{m}\right)$ (Wright 1965) and (2) Slatkin's private allele method (Slatkin 1985) with the correction for sample size (Barton \& Slatkin 1986) as implemented in GENEPOP, online version (Raymond \& Rousset 1995).

Although the standard approach to measure gene flow (and migration rates) is through the use of $F_{\mathrm{ST}}$ (Wright 1965, Neigel 2002), recent developments have produced population genetic software programs with more sophisticated approaches that take into account more of the underlying biology of populations and thereby produce more accurate information (Abdo et al. 2004, Pearse \& Crandall 2004). In fact, although $F_{\text {ST }}$ is theoretically related at equilibrium to migration rates, real populations are very likely to violate the assumptions of the model. Similar $F_{\mathrm{ST}}$ values, for example, might reflect both low gene flow and large $N_{\mathrm{e}}$, or high gene flow and low $N_{\mathrm{e}}$ (Whitlock \& McCauley 1999, Jensen et al. 2005, Fraser et al. 2007). For these reasons, we calculated migration rates (as $N_{\mathrm{e}} \mathrm{m}$ ) by estimating $M=m / \mu$ (migrants per generations scaled by mutation rate) and $\theta=4 N_{\mathrm{e}} \mu$ values with Migrate ver. 2.1.3 software (Beerli \& Felsenstein 1999, 2001). Migrate provides a long-term method of $\theta$ and $M$ estimation based on coalescent theory (Beerli \& Felsenstein 2001) under the assumptions of migration-drift equilibrium, populations constant sizes and gene flow over the coalescent period $\left(\approx 4 N_{\mathrm{e}}\right.$ generations) (Fraser et al. 2007). MiGRATE was successively run using as starting values the estimates obtained from previous runs and the following parameters: microsatellites Ladder model (Ohta \& Kimura 1973, Kimura \& Ohta 1978), 10 short chains (10000 sampled, 500 recorded) and 2 long chains (4000000 sampled, 200000 recorded; number of discarded trees per chain: 400000$)$. The software was run 2 times to assure that final chains were estimating the same values of $\theta$ and $M$. The results obtained from different runs were very similar; thus we report only 1 set of results. Values of $\theta$ were converted to $N_{\mathrm{e}}$ using mutation rates $(\mu)$ of $5 \times 10^{-4}$ (Estoup \& Angers 1998).

Effective population size $\left(N_{\mathrm{e}}\right)$ was also calculated with a heterozygosity-based method (Ohta \& Kimura 1973), which predicts that at mutation-drift equilibrium under the stepwise mutation model (SMM), $N_{\mathrm{e}}$ should equal $\left[\left(1 / 1-H_{\mathrm{e}}\right)^{2}-1\right] / 8 \mu$, where $H_{\mathrm{e}}$ is the observed averaged heterozygosity and the mutation rate, $\mu$, was assumed to be $5 \times 10^{-4}$ according to Estoup \& Angers (1998). Further estimation of $N_{\mathrm{e}}$ was performed using NeEstimator ver. 1.3 (Peel et al. 2004). The software provides point estimation of $N_{\mathrm{e}}$ for single populations; in the present study, the linkage disequilibrium (LD) method by Bartley et al. (1992) was chosen. In particular, the assumptions necessary to estimate $N_{\mathrm{e}}$ from correlations of alleles include neutral alleles, no migration, no subpopulation structure, and a random sampling of the entire population (Hill 1981). The software calculates LD and the correlation among alleles at different loci (r) in a population sample and takes the arithmetic mean of all $\mathrm{r}^{2}$ values to get a single $\mathrm{r}^{2}$ which is used to calculate $N_{\mathrm{e}}$ as in the equation $N_{\mathrm{e}}=1 /\left[3\left(\mathrm{r}^{2} \times\right.\right.$ $1 / S$ )] ( $S=$ sample size) (Campton 1987, Bartley et al. 1992, Peel et al. 2004, Fraser et al. 2007).

\section{RESULTS}

\section{Genetic diversity, Hardy-Weinberg equilibrium, linkage disequilibrium}

The number of alleles per locus ranged from 6 (Ca88) to 93 (Ca21; Table 2). Frequencies of the most common allele (MCAF) at each locus were similar between population samples, except for locus Cr259 that showed the frequency of 0.183 in the South Orkneys population sample compared to the frequencies observed in the other populations that ranged between 0.355 and 0.383. Considering all samples together, the observed heterozygosity ranged from 0.157 to 0.709 , while the expected heterozygosity ranged from 0.208 to 0.945 . A weak excess of homozygotes was found at all loci, except for Ca48 (Table 2).

Hardy-Weinberg equilibrium (HWE) probabilities (Table 2) were calculated for each locus, for each population and combined by Fisher's test for a global value. 


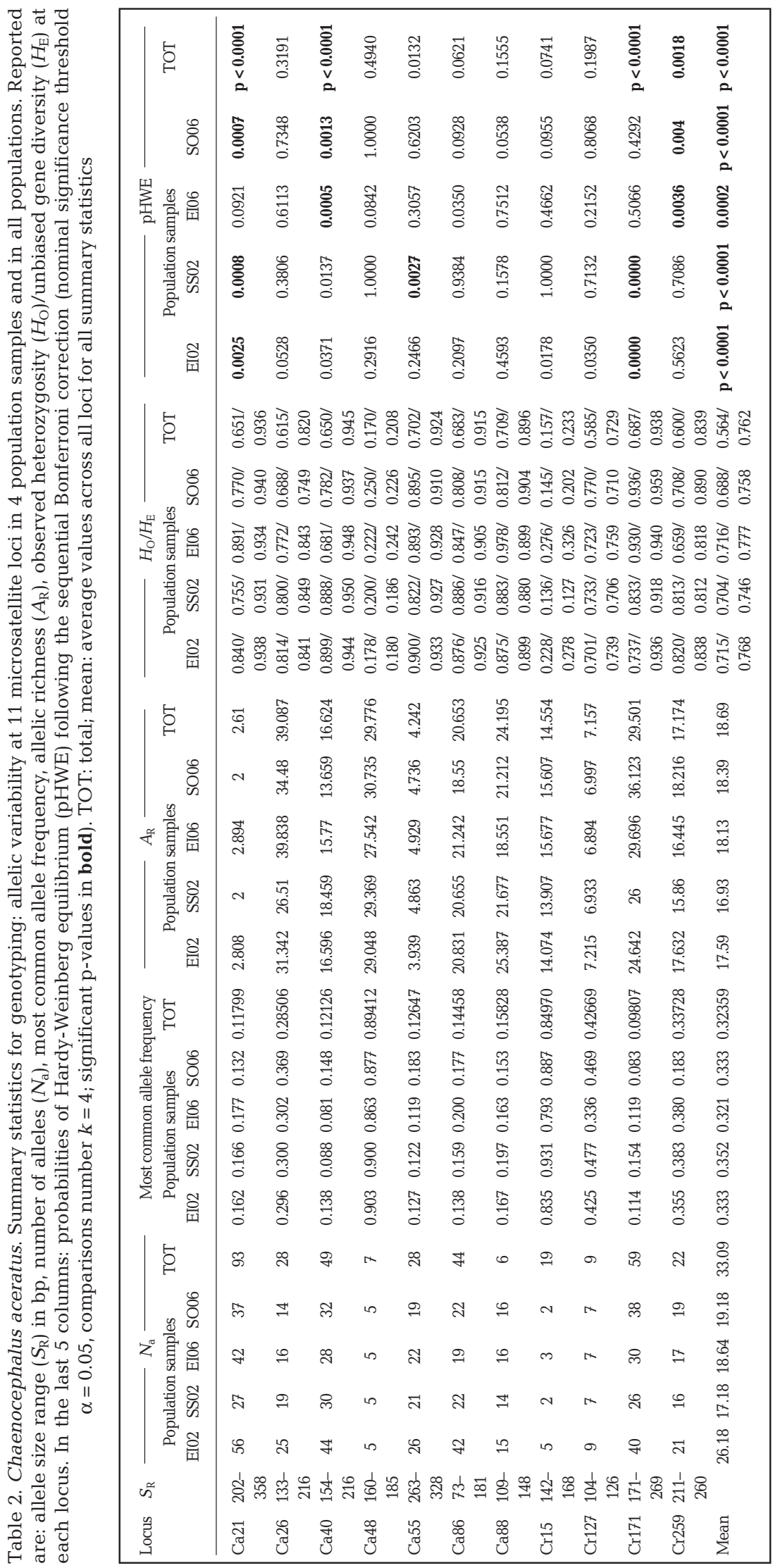

When combining populations, 4 loci (Ca21 and Ca40, Cr171 and Cr259) were in Hardy-Weinberg disequilibrium; these loci were also the most polymorphic, with the highest allelic number (Table 2). For these loci, the software MiCROCHECKER ver. 2.2.3 (van Oosterhout et al. 2004) suggested the presence of null alleles for some population samples (data not shown). Exact tests for linkage disequilibrium yielded no significant values for all loci combinations $(p>0.01$, data not shown). According to results from HWE and MiCROCHECKER, all tests of differentiation were performed both considering and excluding loci that deviated from HWE; however, these loci do not affect the final results (Table 3, Table A1 in Appendix 1; available at: www.int-res. com/articles/suppl/m376p269_app.pdf).

\section{Population structure}

Results of overall population differentiation and pairwise population comparison performed with CHIFISH ver. 1.3 (Ryman 2006) are reported in Tables 3 \& A1 (supplementary materials). Although single-loci p-value estimates varied between these 2 methods (Table A1), results revealed significant differences after sequential Bonferroni corrections in all pairwise comparisons $(p<0.0001)$, except between southern South Shetlands and Elephant Island collected in $2002(p=0.10040$ from Fisher's test and $\mathrm{p}=0.06363$ from chi-squared test). This latter result confirmed, after re-codification of allele classes, the previous results of Papetti et al. (2007). In addition, the present study revealed: (1) temporal differentiation between replicates at similar locations of Elephant Island (2002 and 2006, Fisher's exact test: p < 0.00001 , chi-squared test: $\mathrm{p}<0.00001$ ) and (2) significant genetic heterogeneity at geographic scale between South Orkney (2006) and Elephant Island (both 2002 and 2006, Fisher's exact test: $\mathrm{p}<0.00001$ and chi-squared test: $\mathrm{p}<$ 0.00001 for each comparison). Pairwise $F_{\mathrm{ST}}$ (Table 4) revealed that the largest genetic differentiation was between distant geographic populations including 
Table 3. Chaenocephalus aceratus. Differentiation probability test between population samples. Multilocus p-values were estimated by Fisher's and chisquared methods $\left(\mathrm{p}(\mathrm{Fisher}) / \mathrm{p}\left(\chi^{2}\right)\right)$. * Significant $\mathrm{p}$-values after sequential Bonferroni adjustment. $\mathrm{n}$ loci: number of loci showing significant differences for each differentiation test; all: all loci; without: excluding loci that deviated from Hardy-Weinberg equilibrium

\begin{tabular}{|llcccrrrr}
\hline $\begin{array}{l}\text { Population } \\
\text { sample pairs }\end{array}$ & Loci & $\begin{array}{c}\mathrm{p} \\
\text { (Fisher) }\end{array}$ & $\begin{array}{c}\mathrm{n} \\
\text { loci }\end{array}$ & & $\chi^{2}$ & $\mathrm{df}$ & $\mathrm{p}\left(\chi^{2}\right)$ & $\begin{array}{c}\mathrm{n} \\
\text { loci }\end{array}$ \\
\hline All populations & All & $<0.00001^{*}$ & 7 & 1965.232 & 1059 & $<0.00001$ & 6 \\
& Without & $0.00007^{*}$ & 3 & 539.707 & 402 & 0.00001 & 2 \\
EI02/SS02 & All & 0.10040 & 1 & 328.64 & 291 & 0.06363 & 0 \\
& Without & 0.23417 & 0 & 137.493 & 125 & 0.20974 & 0 \\
EI02/EI06 & All & $<0.00001^{*}$ & 3 & 754.518 & 314 & $<0.00001$ & 5 \\
& Without & 0.01968 & 1 & 163.731 & 126 & 0.01339 & 2 \\
EI02/SO06 & All & $<0.00001^{*}$ & 7 & 797.415 & 322 & $<0.00001$ & 7 \\
& Without & $0.00050^{*}$ & 3 & 187.361 & 125 & 0.00026 & 3 \\
EI06/SS02 & All & $<0.00001^{*}$ & 6 & 430.929 & 254 & $<0.00001$ & 5 \\
& Without & $0.00007^{*}$ & 4 & 150.458 & 100 & 0.00083 & 4 \\
EI06/SO06 & All & $<0.00001^{*}$ & 6 & 385.98 & 261 & $<0.00001$ & 6 \\
& Without & $0.00131^{*}$ & 2 & 140.215 & 97 & 0.00272 & 2 \\
EI02+EI06/SO06 & All & $<0.00001^{*}$ & 7 & 398.246 & 219 & $<0.00001$ & 6 \\
& Without & $<0.00001^{*}$ & 5 & 229.457 & 82 & $<0.00001$ & 5 \\
EI02+EI06/SS02 & All & $<0.00001^{*}$ & 2 & 1212.954 & 652 & $<0.00001$ & 3 \\
& Without & 0.1104 & 0 & 153.299 & 130 & 0.0796 & 0 \\
SS02/SO06 & All & $<0.00001^{*}$ & 5 & 431.518 & 254 & $<0.00001$ & 4 \\
& Without & $0.00106^{*}$ & 2 & 139.331 & 97 & 0.00316 & 2 \\
\hline
\end{tabular}

Table 4. Chaenocephalus aceratus. Estimation of the genetic differentiation based on allele frequencies. $F_{\mathrm{ST}}$ : actual estimate of population differentiation and $95 \%$ confidence interval $\left(F_{\mathrm{ST}} 95 \% \mathrm{CI}\right)_{i} F_{\mathrm{ST}}^{\prime}$ : standardized measure of population divergence

\begin{tabular}{|lcrc|}
\hline Sample pair & $F_{\text {ST }}$ & $95 \%$ CI & $F^{\prime}{ }_{\text {ST }}$ \\
\hline EI02/SS02 & 0.002 & -0.001 to 0.006 & 0.0085 \\
EI02/EI06 & 0.009 & 0.001 to 0.020 & 0.0404 \\
EI02/SO06 & 0.011 & 0.004 to 0.020 & 0.0478 \\
EI06/SS02 & 0.014 & 0.005 to 0.025 & 0.0611 \\
EI06/SS06 & 0.009 & 0.005 to 0.013 & 0.0403 \\
EI02+EI06/SO06 & 0.008 & 0.004 to 0.014 & 0.0358 \\
EI02+EI06/SS02 & 0.003 & 0.000 to 0.007 & 0.0131 \\
SS02/SO06 & 0.015 & 0.005 to 0.024 & 0.0630 \\
\hline
\end{tabular}

Elephant Island (2002) and South Orkneys (2006) $\left(F_{\mathrm{ST}}\right.$ $=0.011$ ) and southern South Shetlands (2002) and South Orkneys (2006) $\left(F_{\mathrm{ST}}=0.015\right)$, whereas the level of genetic differentiation between temporal replicates appears slightly lower $\left(F_{\mathrm{ST}}=0.009\right.$ between Elephant Island 2002 and 2006). This is also true for standardized $F^{\prime}$ ST values (Table 4). A significant relationship between genetic and geographic distance matrixes was confirmed by Mantel's test, alternatively considering 1 of the 2 temporal replicates from Elephant Island (dataset with EI02, $\mathrm{R}^{2}=0.1319 ; \mathrm{p}<0.00001$, after 9999 permutations; dataset with EI06, $\mathrm{R}^{2}=0.1441$; $\mathrm{p}<$ 0.00001, after 9999 permutations). Barriers to the gene flow were graphically represented by BARRIER ver 2.2
(Manni et al. 2004) (Fig. 2), which pointed out a large genetic break (namely Barrier I in Fig. 2) between South Orkney and the southern South Shetlands/Elephant Island.

\section{Gene flow and effective population size}

Levels of gene flow between populations are reported in Table 5 as $N_{\mathrm{e}} \mathrm{m}$ and were calculated following different approaches. Results range from 8.20 to 49.75 migrants per generation indicating a high general gene flow trend between the 2 geographic areas. In particular, while Wright's and Slatkin's methods provide unidirectional gene flow values only, MigRATE ver. 2.1.3 allows calculation of migration into 2 separated gene-flow directions and indicated a rather symmetric gene flow between Elephant Island and South Orkneys in 2006 (Fig. 1b, Table 5). In agreement with previously published studies, effective population size $\left(N_{\mathrm{e}}\right)$ varied considerably between methods (Fraser et al. 2007), with Migrate providing the highest estimates (Table 6); the $N_{\mathrm{e}}$ values are nevertheless different from previous estimates calculated between cohorts considering drift only ( $N_{\mathrm{e}}=96$ in Papetti et al. 2007). In particular, Elephant Island and South Orkney showed higher $N_{\mathrm{e}}$ values than before, also when considering the $95 \%$ confidence intervals (average from 241.4 to 21236.39 for EI06 and from 264.00 and 16491.42 for SO06; Table 6).

\section{DISCUSSION}

The present study reveals a much more complex pattern of differentiation than shown previously in Papetti et al. (2007), as genetic differences occur both at temporal (Elephant Island 2002 and 2006) and at geographic scale between South Shetlands (including Elephant Island) and South Orkney. Interestingly, similar conclusions on geographic differentiation were also reached by parasitic infestation patterns and data on spawning time/maturity stages (Siegel 1980, Sosinski \& Janusz 2000).

The present study, together with the rising number of recent cases such as Gadus morhua and Platichthys flesus (Pogson et al. 2001, Hemmer-Hansen et al. 2007), demonstrates that potentially high effective population size and absence of obvious barriers to 


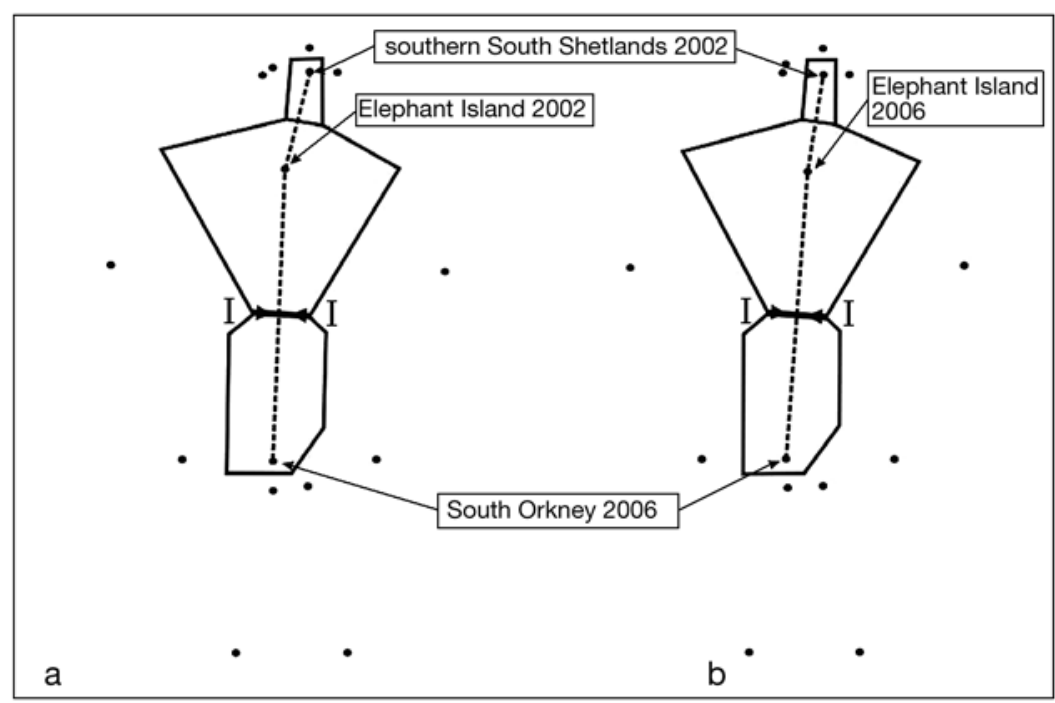

Fig. 2. Genetic boundaries obtained with Monmonier's algorithm, implemented in BARRIER ver. 2.2, indicated by thick solid lines (Barrier I). Thin solid lines represent Voronoï tessellation; dots outside it are virtual points used for Voronoï tessellation; dots inside indicate population samples; the central dashed line represents Delauney triangulation. Since temporal replicates were found to be genetically differentiated, (a) and (b) represent genetic boundaries for 2 different datasets: (a) southern South Shetlands 2002, Elephant Island 2002, and South Orkney 2006; and (b) southern South Shetlands 2002, Elephant Island 2006, and South Orkney 2006

Table 5. Chaenocephalus aceratus. Estimation of the gene flow effective number of migrants per generation $\left(N_{\mathrm{e}} \mathrm{m}\right)$ between population samples collected at Elephant Island and South Orkney, based on different methods: Wright's, Slatkin's, and MigRATE ver. 2.1.3

\begin{tabular}{|lcccc|} 
& \multirow{2}{*}{ Wright's } & Slatkin's & \multicolumn{2}{c|}{ Migrate } \\
\cline { 4 - 5 } & EI06/SO06 & EI06/SO06 & EI06 to SO06 & SO06 to EI06 \\
\hline$N_{\mathrm{e} \text { m }}$ & 27.527 & 8.8147 & 15.986 & 15.513 \\
$95 \%$ CI & 18.98 to 49.75 & 8.205 to 47.174 & 14.253 to 17.816 & 13.992 to 17.182 \\
\hline
\end{tabular}

Table 6. Chaenocephalus aceratus. Estimation of the effective population size $\left(N_{\mathrm{e}}\right)$ for population samples collected at Elephant Island and South Orkney, using the (Ohta \& Kimura 1973) equilibrium formulas under the stepwise mutation model (SMM) and following approaches implemented in 2 software programs: NEESTIMATOR ver. 1.3 and MigRATE ver. 2.1.3

\begin{tabular}{|c|c|c|c|c|}
\hline Sample & $\begin{array}{c}N_{\mathrm{e}} \\
\text { and CI }\end{array}$ & $\begin{array}{l}\text { Heterozygosity } \\
\text { method SMM }\end{array}$ & $\begin{array}{l}\text { NeEstimatoR } \\
\text { Linkage } \\
\text { disequilibrium }\end{array}$ & $\begin{array}{c}\text { MiGRATE } \\
\text { Estimation from } \theta^{b}\end{array}$ \\
\hline EI02 & $\begin{array}{c}N_{\mathrm{e}} \\
95 \% \mathrm{CI}\end{array}$ & $\begin{array}{c}2840.28 \\
987.516 \text { to } 10095.063\end{array}$ & $\begin{array}{c}2300.90 \\
1482.6 \text { to } 5000.8\end{array}$ & $\begin{array}{l}6763.511(\theta=13.527) \\
6357.209 \text { to } 7202.638\end{array}$ \\
\hline EI06 & $N_{\mathrm{e}}$ & 2853.16 & 241.4 & $21236.39(\theta=42.472)$ \\
\hline SO06 & $\begin{array}{c}95 \% \mathrm{CI} \\
N_{\mathrm{e}} \\
95 \% \mathrm{CI}\end{array}$ & $\begin{array}{c}1078.887 \text { to } 10399.259 \\
2321.21 \\
884.8047 \text { to } 7060.348\end{array}$ & $\begin{array}{c}177.20 \text { to } 371.90 \\
264.00 \\
193.60 \text { to } 408.20\end{array}$ & $\begin{array}{l}19977.02 \text { to } 22608.05 \\
16491.42(\theta=32.982) \\
15319.61 \text { to } 17731.43\end{array}$ \\
\hline \multicolumn{5}{|c|}{${ }^{\mathrm{a} O h t a} \&$ Kimura (1973) } \\
\hline
\end{tabular}

gene flow (Ward et al. 1994) cannot prevent population structuring in marine fishes on geographical scales. In several marine species such as $G$. morhua, Sebastes rastrelliger, and Caribbean reef fish, the extent of gene flow predicted from larval development, motility, or time spent as planktonic stage does not, in fact, always match with the observed population structure (Hedgecock 1986, Pogson et al. 2001, Taylor \& Hellberg 2003, Buonaccorsi et al. 2004).

In the present study, the Migrate coalescent approach to estimate directional migration rates has been applied for the first time to an Antarctic fish, suggesting gene flow against the dominant currents from South Orkney to Elephant Island (15.51 $\left.N_{\mathrm{e}} \mathrm{m}\right)$. This result can be explained by adults' backward migration against the ACC and the northward outflow of waters from the Weddell Sea. If confirmed, this hypothesis would imply, from a management perspective, that populations from still-exploited areas might contribute to the genetic pool of areas where fishing is banned. However, considering that the southern South Shetlands/ Elephant Island and South Orkney areas of the Antarctic shelf are separated by a deep-water channel (Philip Passage, 2000 m depth; Schodlok et al. 2002, Brandon et al. 2004) and taking into account the sedentary habitus of Chaenocephalus aceratus adults (Jones et al. 2001), this result needs further investigations. In particular, it is worth noting that unsampled southwesterly or southeasterly populations might contribute immigrants to both Elephant Island and South Orkney populations, producing the observed gene flow pattern. Thus, a more thorough sampling in the distribution area of $C$. aceratus will be crucial to defining individual origin and gene-flow patterns.

On the other hand, the present study revealed a complex differentiation pattern in which temporal genetic differences also play an important role. Together with some examples from both 
unexploited and commercially exploited species (Ruzzante et al. 1999, 2006, Nielsen et al. 2003, Bekkevold et al. 2005, Hede Jørgensen et al. 2005, O'Leary et al. 2006), the present study revealed that significant temporal genetic heterogeneity may occur in a marine fish species. In particular, for Chaenocephalus aceratus, the magnitude of genetic differentiation at a temporal scale (between temporal replicates collected at Elephant Island, $F_{\mathrm{ST}}=0.009, \mathrm{p}<0.0001$ ) indicates that genetic differentiation is not only driven by geographic distance. This result confirms our previous finding of a significant genetic differentiation between year classes (Papetti et al. 2007), indicating the existence of population structure over time. In that case, it was postulated that either recruitment and reproductive success variability, small effective population size, or migration may cause differences over time, while other forces, such as selection, can drive genetic differentiation.

\section{Recruitment and reproductive success variability}

Hedgecock (1994) proposed that temporal genetic variation in marine species may result from a large variance in reproductive success among adults driven by the unpredictability of oceanographic conditions ('sweepstakes' hypothesis, resulting in major discrepancies between observed and effective population sizes). This implies that the resulting cohorts comprise the progeny of a small proportion of the spawning population and may result in significant differences in the genetic composition of recruits over time.

Asynchronies between reproductive activity and suitable environmental conditions could lead to individual reproductive failure as a result of sperm limitation, variation in the availability of food for larvae (match-mismatch hypothesis; Cushing 1975), unpredictable nearshore oceanographic features (membervagrant hypothesis; Sinclair 1988), and predation. The reproductive failure by a significant fraction of the adult population can result in temporal genetic variation (Maes et al. 2006) and a Wahlund effect, which occurs when genetically differentiated populations mix, leading to a reduction of observed heterozygosity (Wahlund 1928, Hoarau et al. 2002, 2007, but see Nielsen et al. 2003). In fact, a general deficit of heterozygotes found in the present study supports this scenario in Chaenocephalus aceratus. In addition, high recruitment variability was reported for this species (Kompowski 1990, Reid et al. 2007) and other Antarctic fish (Hill et al. 2005, Collins et al. 2007), suggesting the importance of variance in reproductive success in these organisms. In particular, for the mackerel icefish Champsocephalus gunnari in South Georgia (Hill et al.
2005) and the Patagonian toothfish Dissostichus eleginoides on the Shag Rocks shelf (Collins et al. 2007), the variability was explained by sea surface temperature (SST) fluctuations. Since C. aceratus and mackerel icefish are both channichthyids covering a similar latitudinal range and exhibiting some similar life history strategies, SST may play an important role in the determination of year-class strength also in C. aceratus (Reid et al. 2007) and, possibly, on its temporal genetic variation.

Differences in spawning time and place have also been implicated in temporal genetic differentiation (McPherson et al. 2003). Similarly to other notothenioids for which the onset of spawning exhibits latitudinal variation, such as Dissostichus eleginoides (Laptikhovsky et al. 2006) and the channichthyid Champsocephalus gunnari (Everson et al. 2001), C. aceratus populations inhabiting the southerly distribution range (South Shetlands) spawn from February to May, whereas northerly (South Georgia) spawning starts 1 or 2 mo earlier (Kock \& Kellermann 1991). Moreover, mature individuals of this species are believed to move seasonally inshore to spawn in shallow coastal waters $(<200 \mathrm{~m})$, where they deposit eggs on the seabed and actively guard them (Detrich et al. 2005) until $4 \mathrm{mo}$, when larvae hatch (Kock \& Jones 2002). Whereas the latitudinal breadth of the South Shetlands/South Georgia area is extreme and not comparable with the sampling area considered in the present study, shifts in reproduction times together with temporal variation in oceanographic conditions creates significant potential for temporal variation in recruitment and year-class distribution. In particular, following the predicted source-sink relationship based on regional circulation patterns (Fach \& Klinck 2006), the temporal genetic differentiation observed at Elephant Island could be the result of a variable recruitment from populations located in the far southwest, in the Antartic Peninsula.

Moreover, we cannot exclude the possibility that within the same spawning season, more than one spawning group of Chaenocephalus aceratus may occupy the same spawning ground at different times in 'spawning waves' as documented for instance in the Atlantic and Pacific herring (Lambert 1987). In these species, age structure determines the number of spawning waves per season in a population, with older herring arriving earlier in the season than smaller, younger ones (Lambert 1987, Hede Jørgensen et al. 2005). Different spawning events involving heterogeneous and possibly small groups of spawning individuals may therefore originate different assemblages of larvae by drift (So et al. 2006). This might represent an important reproductive strategy to maximize the survival rate of early life stages by spreading the effort 
over time to take advantage of (or to cope with) a variable environment (Lambert 1987), and it may partly explain the relationship between effective population size and observed census population size, as proposed by the 'sweepstakes' hypothesis (Hedgecock 1994).

\section{Effective population size and migration}

The present study provides the first estimations of long-term effective population size for Chaenocephalus aceratus. The combination of several analytical approaches, including Migrate and NeEstimator, indicates average values of $N_{\mathrm{e}}$ ranging from 241.4 to 21 236.39, with strong differences between methods (Table 6). These are long-term equilibrium estimates, calculated under simplified population models, and may become inaccurate if models' assumptions are violated (Whitlock \& McCauley 1999, Fraser et al. 2007). Taking into account these limitations, our $N_{\mathrm{e}}$ values seem to indicate a relatively large population size in $C$. aceratus, which has been described as one of the most abundant species occurring in the Atlantic Ocean sector of the Southern Ocean (Kock \& Stransky 2000). Considering that an effective population size of at least 50 individuals seems to be sufficient to prevent short-term loss of heterozygosity and 500 to maintain long-term adaptability (Frankham et al. 2002); our $N_{\mathrm{e}}$ estimates seem to indicate that the species is not prone to genetic erosion at the evolutionary time-scale.

On the other hand, contemporary $N_{\mathrm{e}}$ has been shown to be generally lower than its long-term counterpart (Fraser et al. 2007) and has been provisionally estimated, taking into account only differentiation between age classes, at about 100 individuals for Elephant Island in 2002 (Papetti et al. 2007). This discrepancy suggests the importance of non-equilibrium processes in determining temporal fluctuations, and prompts for a rigorous estimation of contemporary $N_{\mathrm{e}}$ with temporal methods, which was not possible in the present study because of the presence of overlapping generations and the short time interval separating our temporal replicates (Jorde \& Ryman 1995).

Similarly, it is interesting to consider our equilibrium estimates of gene flow (Fig. 1b, Table 5). Assuming an island model (Wright 1978), Waples \& Gaggiotti (2006) suggested that a minimum of 5 or alternatively 25 effective migrants per generation are sufficient to prevent population differentiation (evolutionary population definition EV3 and EV4; Waples \& Gaggiotti 2006). Thus, our gene-flow values ranging from 8.20 to 48.75 between different geographic locations should result in a single homogeneous population in the long run, and immigration from differentiated populations can hardly be invoked to explain temporal fluctuations at the same locality using this simplified gene-flow model.

While Chaenocephalus aceratus was expected to show a comparable differentiation pattern to that documented for many marine species with comparable high gene flow and $N_{\mathrm{e}}$ (Hellberg et al. 2002), the present study indicated that $C$. aceratus is complexly structured, and a foremost subdivision boundary (temporal or geographic) between populations remains unclear. It is likely that shifts in spawning time and place, together with a certain degree of migration and a temporally variable complex stepping-stone scenario, generate a subtle population subdivision that is difficult to model with standard approaches.

In conclusion, our results suggest that Chaenocephalus aceratus populations may be genetically isolated from one another and, as fishery stocks, would deserve appropriate conservation policies. We also demonstrated a high level of genetic flow possibly acting against prevailing oceanographic conditions, across the off-shelf/deep-water habitat. Alternatively, this pattern can be produced by source populations contributing to both south Shetlands and South Orkney. In this sense, we cannot exclude the presence of additional differentiated populations in the AP that could also be responsible for the observed temporal variation. With the obvious difficulties in collecting samples in Antarctica, coordinated international efforts should be made to properly address these hypotheses.

At present, our results of geographic differentiation, high gene flow, and temporal variability should be taken into account when defining conservation measures and management boundaries in regions where the fishery is still open or where other Antarctic fish species are still exploited.

Acknowledgements. This work was supported by the Italian National Program for Research in Antarctica (PNRA) (grant to T.P.). We thank K. H. Kock and AWI (Alfred-Wegener-Institute für Polar- und Meeresforschung) that allowed us to collect the 2002 samples during the ANT-XIX/3 'Polarstern' cruise. We thank J. Rock and T. North for providing us the 2006 samples analyzed in this study and collected during the JR145 cruise of the 'James Clark Ross' (British Antarctic Survey) thanks to a Natural Environment Research Council grant, NERC AFI 6/16, to G. Carvalho, Bangor University, UK. We also thank M. Langgaard Madsen for figures and maps improvement.

\section{LITERATURE CITED}

Abdo Z, Crandall KA, Joyce P (2004) Evaluating the performance of likelihood methods for detecting population structure and migration. Mol Ecol 13:837-851

Amos W, Hoffman JI, Frodsham A, Zhang L, Best S, Hill AVS (2007) Automated binning of microsatellite alleles: prob- 
lems and solutions. Mol Ecol Notes 7:10-14

Bartley D, Bagley M, Gall G, Bentley B (1992) Use of linkage disequilibrium data to estimate effective size of hatchery and natural fish populations. Conserv Biol 6:365-375

Barton NH, Slatkin M (1986) A quasi-equilibrium theory of the distribution of rare alleles in a subdivided population. Heredity 56:409-416

Beerli P, Felsenstein J (1999) Maximum-likelihood estimation of migration rates and effective population numbers in two populations using a coalescent approach. Genetics 152: 763-773

Beerli P, Felsenstein J (2001) Maximum likelihood estimation of a migration matrix and effective population sizes in $n$ subpopulations by using a coalescent approach. Proc Natl Acad Sci USA 98:4563-4568

Bekkevold D, Andre C, Dahlgren TG, Clausen LA and others (2005) Environmental correlates of population differentiation in Atlantic herring. Evolution 59:2656-2668

Brandon MA, Naganobu M, Demer DA, Chernyshkov P and others (2004) Physical oceanography in the Scotia Sea during the CCAMLR 2000 survey austral summer 2000 . Deep-Sea Res Part II 51:1301-1321

Buonaccorsi VP, Westerman M, Stannard J, Kimbrell C, Lynn E, Vetter RD (2004) Molecular genetic structure suggests limited larval dispersal in grass rockfish, Sebastes rastrelliger. Mar Biol 145:779-788

Campton D (1987) Natural hybridization and introgression in fishes: methods of detection and genetic interpretations. In: Ryman N, Utter F (eds) Population genetics and fishery management. University of Washington Press, Seattle, WA, p 161-192

> Collins MA, Ross KA, Belchier M, Reid K (2007) Distribution and diet of juvenile patagonian toothfish on the South Georgia and shag rocks shelves (Southern ocean). Mar Biol 152:135-147

Cunningham SA, Alderson SG, King BA, Brandon MA (2003) Transport and variability of the Antarctic Circumpolar Current in Drake Passage. J Geophys Res 108(C5):8084

Cushing DH (1975) Marine ecology and fisheries. Cambridge University Press, Cambridge

> Dannewitz J, Maes GE, Johansson L, Wickstrom H, Volckaert FAM, Jarvi T (2005) Panmixia in the European eel: a matter of time. Proc R Soc Lond B 272:1129-1137

Detrich HW, Jones CD, Kim S, North AW, Thurber A, Vacchi M (2005) Nesting behavior of the icefish Chaenocephalus aceratus at Bouvetoya Island, Southern Ocean. Polar Biol 28:828-832

Estoup A, Angers B (1998) Microsatellites and minisatellites for molecular ecology: theoretical and empirical considerations. IOS Press, Amsterdam

Everson I, North AW, Paul A, Cooper R, McWilliam NC, Kock KH (2001) Spawning locations of mackerel icefish at South Georgia. CCAMLR Sci 8:107-118

Fach BA, Klinck JM (2006) Transport of Antarctic krill (Euphausia superba) across the Scotia Sea. I. Circulation and particle tracking simulations. Deep-Sea Res I 53: 987-1010

FAO (Food and Agriculture Organization of the United Nations) (2001) Ecosystem-based management of fisheries. Opportunities and challenges for coordination between marine regional fishery bodies and regional seas conventions. FAO, Rome. Available at: www.fao.org/ docrep/meeting/003/x9377e.htm

> Flores H, Kock KH, Wilhelms S, Jones CD (2004) Diet of two icefish species from the South Shetland Islands and Elephant Island, Champsocephalus gunnari and Chaenocephalus aceratus. Polar Biol 27:119-129
Frank KT, Brickman D (2001) Contemporary management issues confronting fisheries science. J Sea Res 45:173-187

Frankham R, Ballou JD, Briscoe DA (2002) Introduction to conservation genetics. Cambridge University Press, Cambridge

Fraser DJ, Hansen MM, Ostergaard S, Tessier N, Legault M, Bernatchez L (2007) Comparative estimation of effective population sizes and temporal gene flow in two contrasting population systems. Mol Ecol 16:3866-3889

Goudet J (1995) FSTAT (version 1.2): a computer program to calculate F-statistics. J Hered 86:485-486

Hauser L, Adcock GJ, Smith PJ, Ramirez JHB, Carvalho GR (2002) Loss of microsatellite diversity and low effective population size in an overexploited population of New Zealand snapper (Pagrus auratus). Proc Natl Acad Sci USA 99:11742-11747

Hede Jørgensen H, Hansen M, Loeschcke V (2005) Springspawning herring (Clupea harengus L.) in the southwestern Baltic Sea: Do they form genetically distinct spawning waves? ICES J Mar Sci 62:1065-1075

Hedgecock D (1986) Is gene flow from pelagic larval dispersal important in the adaptation and evolution of marine invertebrates? Bull Mar Sci 39:550-564

Hedgecock D (1994) Does variance in reproductive success limit effective population sizes of marine organisms? In: Beaumont A (ed) Genetics and evolution of aquatic organisms. Chapman \& Hall, London, p 122-134

Hedgecock D, Li G, Hubert S, Bucklin K, Ribes V (2004) Widespread null alleles and poor cross-species amplification of microsatellite DNA loci cloned from the Pacific oyster, Crassostrea gigas. J Shellfish Res 23:379-385

$>$ Hedrick PW (2005) A standardized genetic differentiation measure. Evolution 59:1633-1638

Hellberg ME, Burton RS, Neigel JE, Palumbi SR (2002) Genetic assessment of connectivity among marine populations. Bull Mar Sci 70:273-290

- Hemmer-Hansen J, Nielsen EE, Frydenberg J, Loeschcke V (2007) Adaptive divergence in a high gene flow environment: Hsc70 variation in the European flounder (Platichthys flesus L.). Heredity 99:592-600

> Hemmingsen EA, Douglas EL (1970) Ultraviolet radiation thresholds for corneal injury in Antarctic and temperate zone animals. Comp Biochem Physiol 32:593-600

Hill WG (1981) Estimation of effective population size from data on linkage disequilibrium. Genet Res 38:209-216

Hill SL, Reid K, North AW (2005) Recruitment of mackerel icefish (Champsocephalus gunnari) at South Georgia indicated by predator diets and its relationship with sea surface temperature. Can J Fish Aquat Sci 62:2530-2537

> Hoarau G, Rijnsdorp AD, Van Der Veer HW, Stam WT, Olsen JL (2002) Population structure of plaice (Pleuronectes platessa L.) in northern Europe: microsatellites revealed large-scale spatial and temporal homogeneity. Mol Ecol 11:1165-1176

- Hoareau TB, Bosc P, Valade P, Berrebi P (2007) Gene flow and genetic structure of Sicyopterus lagocephalus in the south-western Indian Ocean, assessed by intron-length polymorphism. J Exp Mar Biol Ecol 349:223-234

Jensen JL, Bohonak AJ, Kelley ST (2005) Isolation by distance, web service. BMC Genet 6:13

Jones CD, Kock KH, Wilhelm S, Ramm D and others (2001) Bottom trawl survey and finfish research in the South Shetland Islands. In: Lipsky J (ed) AMLR 2000/2001 Field Season Report. NOAA-TM-NMFS-SWFSC-314, La Jolla, CA, p 112-149

$>$ Jorde PE, Ryman N (1995) Temporal allele frequency change and estimation of effective size in populations with over- 
lapping generations. Genetics 139:1077-1090

Kimura M, Ohta T (1978) Stepwise mutation model and distribution of allelic frequencies in a finite population. Proc Natl Acad Sci USA 75:2868-2872

Kock K (1992) Antarctic fish and fisheries. Cambridge University Press, Cambridge

Kock KH (2005) Antarctic icefishes (Channichthyidae): a unique family of fishes. A review. I. Polar Biol 28: 862-895

Kock KH, Jones CD (2002) The biology of the icefish Cryodraco antarcticus Dollo, 1900 (Pisces, Channichthyidae) in the southern Scotia Arc (Antarctica). Polar Biol 25: $416-424$

Kock KH, Jones CD (2005) Fish stocks in the southern Scotia Arc region - a review and prospects for future research. Rev Fish Sci 13:75-108

Kock KH, Kellermann A (1991) Reproduction in Antarctic notothenioid fish. Antarct Sci 3:125-150

Kock KH, Möller H (1977) On the occurence of the parasitic copepod Eubrachiella antartica on some Antarctic fish. Arch FischWiss 28:149-156

Kock KH, Stransky C (2000) The composition of the coastal fish fauna around Elephant Island (South Shetland Islands, Antarctica). Polar Biol 23:825-832

Kock KH, Jones CD, Wilhelms S (2000) Biological characteristics of Antarctic fish stocks in the southern Scotia Arc region. CCAMLR Sci 7:1-41

Kompowski A (1990) Studies on the composition of the stock of Chaenocephalus aceratus (Lönnberg, 1906), Pisces, Channichthyidae, in the region of South Georgia and South Shetlands. Acta Ichthyol Pisc 20:29-44

La Mesa M, Ashford J, Larson E, Vacchi M (2004) Age and growth of Scotia sea icefish, Chaenocephalus aceratus, from the south Shetland islands. Antarct Sci 16:253-262

Lambert TC (1987) Duration and intensity of spawning in herring Clupea harengus as related to the age structure of the mature population. Mar Ecol Prog Ser 39:209-220

- Laptikhovsky V, Arkhipkin A, Brickle P (2006) Distribution and reproduction of the Patagonian toothfish Dissostichus eleginoides Smitt around the Falkland Islands. J Fish Biol 68:849-861

Liu K, Muse SV (2005) POWerMarker: an integrated analysis environment for genetic marker analysis. Bioinformatics 21:2128-2129

Lundy CJ, Rico C, Hewitt GM (2000) Temporal and spatial genetic variation in spawning grounds of European hake (Merluccius merluccius) in the Bay of Biscay. Mol Ecol 9:2067-2079

> Maes GE, Pujolar JM, Hellemans B, Volckaert FAM (2006) Evidence for isolation by time in the European eel (Anguilla anguilla L.). Mol Ecol 15:2095-2107

Manni F, Guérard E, Heyer E (2004) Geographic patterns of (genetic, morphologic, linguistic) variation: how barriers can be detected by 'Monmonier's algorithm'. Hum Biol 76:173-190

McPherson AA, Stephenson RL, Taggart CT (2003) Genetically different Atlantic herring Clupea harengus spawning waves. Mar Ecol Prog Ser 247:303-309

McQuinn IH (1997) Metapopulations and the Atlantic herring. Rev Fish Biol Fish 7:297-329

Moffat C, Beardsley RC, Owens B, van Lipzig N (2008) A first description of the Antarctic Peninsula Coastal Current. Deep-Sea Res II 55:277-293

Monmonier M (1973) Maximum-difference barriers: an alternative numerical regionalization method. Geogr Anal 3: 245-261

> Naveira Garabato AC, McDonagh EL, Stevens DP, Heywood KJ, Sanders RJ (2002) On the export of Antarctic Bottom
Water from the Weddell Sea. Deep-Sea Res II 49: 4715-4742 Neigel JE (2002) Is $F_{\mathrm{ST}}$ obsolete? Conserv Genet 3:167-173

Nielsen EE, Hansen MM, Ruzzante DE, Meldrup D, Gronkjaer P (2003) Evidence of a hybrid-zone in Atlantic cod (Gadus morhua) in the Baltic and the Danish Belt Sea revealed by individual admixture analysis. Mol Ecol 12:1497-1508

O'Leary DB, Coughlan J, McCarthy TV, Cross TF (2006) Application of a rapid method of SNP analysis (glycosylase mediated polymorphism detection) to mtDNA and nuclear DNA of cod Gadus morhua. J Fish Biol 69:145-153

Ohta T, Kimura M (1973) A model of mutation appropriate to estimate the number of electrophoretically detectable alleles in a finite population. Genet Res 22:201-204

> Orsi AH, Whitworth T III, Nowlin WD Jr (1995) On the meridional extent and fronts of the Antarctic Circumpolar Current. Deep-Sea Res I 42:641-673

Papetti C, Zane L, Patarnello T (2006) Isolation and characterization of microsatellite loci in the icefish Chionodraco rastrospinosus (Perciformes, Notothenioidea, Channichthyidae). Mol Ecol Notes 6:207-209

Papetti C, Susana E, La Mesa M, Kock KH, Patarnello T, Zane L (2007) Microsatellite analysis reveals genetic differentiation between year-classes in the icefish Chaenocephalus aceratus at South Shetlands and Elephant Island. Polar Biol 30:1605-1613

Patarnello T, Volckaert FAMJ, Castilho R (2007) Pillars of Hercules: Is the Atlantic-Mediterranean transition a phylogeographical break? Mol Ecol 16:4426-4444

Patwary MU, Kenchington EL, Bird CJ, Zouros E (1994) The use of random amplified polymorphic DNA markers in genetic studies of the sea-scallop Placopecten magellanicus (Gmelin, 1791). J Shellfish Res 13:547-553

> Peakall R, Smouse PE (2006) GENAlEx 6: genetic analysis in Excel. Population genetic software for teaching and research. Mol Ecol Notes 6:288-295

$>$ Pearse DE, Crandall KA (2004) Beyond $F_{\mathrm{ST}}$ : analysis of population genetic data for conservation. Conserv Genet 5: $585-602$

Peel D, Ovenden JR, Peel SL (2004) NeEstimator: software for estimating effective population size, version 1.3. Queensland Government, Department of Primary Industries and Fisheries, St. Lucia

> Pogson GH, Taggart CT, Mesa KA, Boutilier RG (2001) Isolation by distance in the Atlantic cod, Gadus morhua, at large and small geographic scales. Evolution 55:131-146

Raymond M, Rousset F (1995) GENEPOP (version-1.2): population genetics software for exact tests and ecumenicism. J Hered 86:248-249

Reid WDK, Clarke S, Collins MA, Belchier M (2007) Distribution and ecology of Chaenocephalus aceratus (Channichthyidae) around South Georgia and Shag Rocks (Southern Ocean). Polar Biol 30:1523-1533

Rice WR (1989) Analyzing tables of statistical tests. Evolution 43:223-225

Ruzzante DE, Taggart CT, Cook D (1999) A review of the evidence for genetic structure of cod (Gadus morhua) populations in the NW Atlantic and population affinities of larval cod off Newfoundland and the Gulf of St. Lawrence. Fish Res 43:79-97

Ruzzante DE, Mariani S, Bekkevold D, André C and others (2006) Biocomplexity in a highly migratory pelagic marine fish, Atlantic herring. Proc Biol Sci 273(1593):1459-1464

Ryman N (2006) CHIFISH: a computer program testing for genetic heterogeneity at multiple loci using chi-square and Fisher's exact test. Mol Ecol Notes 6:285-287

Ryman N, Jorde PE (2001) Statistical power when testing for genetic differentiation. Mol Ecol 10:2361-2373 
Schodlok MP, Hellmer HH, Beckmann A (2002) On the transport variability and origin of dense water masses crossing the South Scotia Ridge. Deep-Sea Res II 49:4807-4825

Siegel V (1980) Quantitative investigations on parasites of Antarctic channichthyid and nototheniid fishes. Meeresforschung 28:146-156

Sinclair M (1988) Marine populations. An assay on population regulation and speciation. University of Washington Press, Seattle, WA

Slatkin M (1985) Gene flow in natural populations. Annu Rev Ecol Syst 16:393-430

Smouse PE (1986) The fitness consequences of multiple-locus heterozygosity under the multiplicative overdominance and inbreeding depression models. Evolution 40:946-958

So N, Maes GE, Volckaert FAMJ (2006) Intra-annual genetic variation in the downstream larval drift of sutchi catfish (Pangasianodon hypophthalmus) in the Mekong river. Biol J Linn Soc 89:719-728

Sosinski J, Janusz J (2000) Infection variability of the parasitic copepod Eubrachiella antarctica (Quidor, 1906) on fishes in the Atlantic sector of the Antarctic. Bull Sea Fish Inst 2:25-42

Susana E, Papetti C, Barbisan F, Bortolotto E, Buccoli S, Patarnello T, Zane L (2007) Isolation and characterization of eight microsatellite loci in the icefish Chaenocephalus aceratus (Perciformes, Notothenioidei, Channichthyidae). Mol Ecol Notes 7:791-793

Editorial responsibility: Andrew Brierley, St. Andrews, UK
Takahashi M, Iwami T (1997) The summer diet of demersal fish at the South Shetland Islands. Antarct Sci 9:407-413

Taylor MS, Hellberg ME (2003) Genetic evidence for local retention of pelagic larvae in a Caribbean reef fish. Science 299:107-109

> van Oosterhout C, Hutchinson WF, Wills DPM, Shipley P (2004) Micro-Checker: software for identifying and correcting genotyping errors in microsatellite data. Mol Ecol Notes 4:535-538

Wahlund S (1928) The combination of populations and the appearance of correlation examined from the standpoint of the study of heredity. Hereditas 11:65-106

> Waples RS, Gaggiotti OE (2006) What is a population? An empirical evaluation of some genetic methods for identifying the number of gene pools and their degree of connectivity. Mol Ecol 15:1419-1439

Ward RD, Woodwark M, Skibinski DOF (1994) A comparison of genetic diversity levels in marine, freshwater, and anadromous fishes. J Fish Biol 44:213?232

Whitlock MC, McCauley DE (1999) Indirect measures of gene flow and migration: $F_{\mathrm{ST}} 1 /(4 N m+1)$. Heredity $82: 117-125$

> Wright S (1965) The interpretation of population structure by F-statistics with special regard to systems of mating. Evolution 19:395-420

Wright S (1978) Evolution and the genetics of populations, Vol 4. Variability within and among natural populations. University of Chicago Press, Chicago, IL

Submitted: March 13, 2008; Accepted: November 14, 2008 Proofs received from author(s): January 31, 2009 